\title{
Roads to Recursion. Some historiographical remarks on a core category of Media Art
}

\section{Los caminos de la recursividad. Algunas observaciones historiográficas sobre una categoría central del Media Art}

\author{
Slavko Kacunko \\ Professor in Art History and Visual Culture (Copenhagen University)
}

Fecha de recepción: 6 de marzo de 2014

Fecha de revisión: 4 de julio de 2014

Para citar este artículo: Kacunko, S. (2014): Roads to Recursion. Some historiographical remarks on a core category of Media Art, Icono 14, volumen (12), pp. 70-85. doi: 10.7195/ri14.v12i2.682 


\section{Abstract}

In this paper, the general arena between analogue and digital media art is explored with special respect to the concept of the 'newness' of media. The first part confirms the Closed Circuit as an 'open system' related to its right to an evolution towards increasing complexity without the reciprocal playing-off of self-referential 'life' against 'hetero-referential' technique. The second part refers to the continuity of research undertaken in media, art and art-history and discussion in related fields while the concepts of 'new' media have repeatedly admitted the Closed Circuit as a core category in 'New' Media Art. The third part introduces one content-related categorization of Closed Circuit video installations which has been regarded as representative for the general 'fields of inquiry' of both analogue and digital media art.

Key Words: Video - Closed Circuit - Installation

\section{Resumen}

En este trabajo, se explora el ámbito general entre lo analógico y el "Media Art" digital con especial respeto al concepto de "novedad" en los medios de comunicación. La primera parte confirma el Circuito Cerrado como un "sistema abierto" en relación con su derecho a una evolución hacia una mayor complejidad. La segunda parte se refiere a la continuidad de la investigación llevada a cabo en los medios de comunicación, el arte y la historia del arte y la discusión en campos relacionados, mientras que el concepto de "nuevos" medios de comunicación ha admitido varias veces el circuito cerrado como una categoría central en 'New' $\mathrm{Me}$ dia Art". La tercera parte presenta una categorización de contenidos relacionados con las instalaciones de vídeo de circuito cerrado que ha sido considerada como representativa de los "campos de investigación" generales de lo analógico y el "Media Art Digital".

Palabras clave: Vídeo - Circuito Cerrado - Instalación

ICONO14 | Año 2014 Volumen 12 N² 2 | ISSN: 1697-8293 | DOI: ri14.v12i2.682 
Roads to Recursion. Some historiographical remarks on a core category of Media Art | 72

\section{Introduction}

We experience the world as a narrative, and that applies also to most digitized artifacts. But from the perspective of the digital ontology, the so-called 'new media objects' (DVD, Blu-ray disc etc.) cannot be regarded any more as narratives like a novel or cinema - they are just databases organized by algorithms, as Lev Manovich has been claiming since the mid-1990s. ${ }^{1}$ Regarding this seeming contradiction we are very well aware of the need to organize our digitized data properly according to non-recursive rules. From the digital perspective this is the way to get the added value produced by the cross-reference possibilities of (for instance) relational data bases. On the other hand, we need to organize all kinds of computerized collections according to our analogue (sensual, aesthetic ${ }^{2}$ ) experience, and not least we need to reflect and understand how this experience is being newly structured in the process, in a similar way to the material world around us.

The first, rather reductionist side of the media-historiographical coin includes the view that there are only two kinds of digital objects: databases and algorithms. According to it, our task would be to project this ontology of the computer onto culture itself. The other side of the coin derives from our common, more holistic experience and has to do with our need to store, to transmit and to develop classifications and standards for orientation within our basically unstable, processual experience.

Stacked between the inevitable reductionist, digital and 'scientific' approaches on one side and the holistic, analog and personal on the other, the repeated failures of either-or-solutions have revealed the still unfulfilled need for improved, advanced methods and for an agenda of the asymptotic reaching a sustainable balance. It seems to be obvious: when the map is larger than the mapped, the process of mapping in itself and by nature becomes the major cultural issue. There is a tendency for the host to be captured by the hosted. In such situations, all involved may take an opportunity to reconsider the adjustability of their own concepts of appraisal and archival storage, towards a fresh historiography of media. In what follows, I will take analogue and digital media art as an historical model for some recursive observations ${ }^{3}$ on the 'newness' of media in the historiographical context.

DOI: ri14.v12i2.682 | ISSN: 1697-8293 | Año 2014 Volumen 12 №2 | ICONO14 
The Closed Circuit will be examined as one of the core categories both for the historiography of media art and of the so called 'new' media themselves.

\section{Closed Circuit as an Open System: Method}

The definitions of Closed Circuit ${ }^{4}$ are the most prominent points of departure for the historiography of 'video art' and of 'media art' as a whole. In this section I will briefly outline several related academic standpoints on Closed Circuit which reflect the historiographical relevance of the issue.

In applying the term 'feedback' to both, Closed Circuit ("geschlossenen Kreislauf') and closed loop, many authors have risked leaving the misleading impression that the term applies only to those Closed Circuit video installations which generate a feed-back image (Schwarz 19975\% Donga 1998 ${ }^{6}$ ). In fact, video feedback means the input-output relationship between the devices concerned - the technical prerequisites for a live video image and the constituent elements for any Closed Circuit video installation. It is insignificant whether a fed back image is thus produced or not.

Gene Youngblood dedicated a chapter of his book Expanded Cinema (1970) to this theme, entitling it, "Closed-Circuit Television and Teledynamic Environments". Youngblood defined the Closed Circuit video installation as a "teledynamic environment" and even termed it the "only pure television art" (Youngblood 19707). Jud Yalkut has adopted Youngblood's definition of Closed Circuit video installation as "teledynamic" video space and has highlighted "self-visibility", instantaneousness and a televisually deconstructive aesthetic as its most important characteristics, being indicative of its artistic potential (Yalkut $1974^{\circ}$ ). At the same time, in his critical evaluation of videotape-art, Allan Kaprow has described tapeless Closed Circuit video installations as the "only interesting video art" (Kaprow 1974").

In a résumé dating from the beginning of the 1990s, Wulf Herzogenrath drew attention additionally to the fact, that since the 1970s, Closed Circuit video installations had also become a dominant feature of everyday life, whether as a means of surveillance in the banks and public places or in the electronics trade. The unity of

ICONO14 | Año 2014 Volumen 12 Nº 2 | ISSN: 1697-8293 | DOI: ri14.v12i2.682 
Roads to Recursion. Some historiographical remarks on a core category of Media Art | 74

time and space and of reality and image contributed to the viewer's metamorphosis into a "Doppelgänger", and demonstrated

"that this direct involvement of an individual viewer can lead, in the complex technology of mass communication, to an individualisation in these art works of a single person. The structure determined by the artist is only completed on the entry into the proceedings, and in the complicity, of the individual viewer. His own experience, existential questions about his own image, about the 'true' reality of the image and of the shadow become the theme here."10

Seen apart from the varied range of (mis-)conceptions, there is consensus to date about the 'primacy' of Closed Circuit video installation and performance as far as the artistic application of the video medium is concerned (Frieling 199911; Rush $\left.1999^{12}\right)$. An emphasis on methods of video application 'appropriate' to the medium in the sense of real-time transmission has remained a recurring theme (Kahlen $1980^{13}$; Ross $1995^{14}$ ). David Ross, the first head of a museum video department and curator of several important early video exhibitions in the USA, depicted the early appearance of 'video art' as "the perfect manifestation of the myth of avant-garde artistic practice" and of a "de-materialized artmaking" as an "explicit challenge to the hegemony of the modern museum"- a cult of instantaneous experience, which however will make sense only when we talk about the video experience taking place in a Closed Circuit arrangement. Ross went on to describe the polarization which also characterized the early 'video community' from the start:

“Those seeking an electronic palette for the creation of a glowing, digitalized painting technique were sadly mistaking the name of the thing for the thing itself, and were clearly blinded to the critically distinctive properties of the medium: immediacy, the ability to reconstruct the notion of a time-based audience, and the ability to faithfully create fully credible representations of real time." ${ }^{15}$

Both the instantaneousness and site-specificity have been identified and simultaneously extended to cultural-translational and anthropological practices. In a text

DOI: ri14.v12i2.682 | ISSN: 1697-8293 | Año 2014 Volumen 12 №2 | ICONO14 
entitled "Video, Art of the Cultural Difference", Juan Downey described the impact of an experience of Closed Circuit video as he witnessed it among the Yanomami Indians in a remote area of the Amazon, completely cut off from the rest of the world:

“Video, as process or as instrument, impresses the Yanomami no more that an outboard motor, a shotgun, or a flashlight. From the point of view of the Indians, television is simply yet another thing that the 'strangers' make, as desirable as any other consumer goods [...]. Closed-circuit or live television appeared to them no more surprising than a mirror, and the fact that the videotape requires no developing did not interest them, for the simple reason that they do not know about the cinema and its slow laboratory processing. The closed circuit and the freedom from processing, then, are advantages not inherent in video but rather in comparison with cinema; a catalyzing process in our culture, but not in the Yanomami's." ${ }^{16}$

At the same time, Eugeni Bonet has pointed out with respect to the Western cultures that in the case of Closed Circuit "we must not forget the full form of the term: closed circuit TV. This means that the signal recorded by the camera is not emitted by the air, but remains 'closed' in the cable which transports it to the terminal-screen."17 Bonet correctly portrayed the analogous time delay as one of the most important achievements of early Closed Circuit video installations. As far as the present view on Closed Circuit video installations is concerned, no defining difference is seen between video signals and data transmitted via cable or via microwave emission, or, indeed, via other means of broadcasting. What is key is whether the transmission is 'point-to-point', and not merely a one-way 'broadcasting' to many transmission points or households from a central point, which would conform to the concept of 'mass media'. In contrast to what is described as 'open circuit', the same technology could be used for the purposes of a bilateral or multilateral exchange of information, as is the case in the Closed Circuit between input and output signal. The two technical terms denote opposite strategies in their current use of the interactive potential of the medium: while the technological 'open circuit' means a closed, non-interactive system, the technologically closed Closed Circuit refers (apparently paradoxically) to the openness of the system to the unpredictable influences of the environment, enabled by the positive feedback between par-

ICONO14 | Año 2014 Volumen 12 N² 2 | ISSN: 1697-8293 | DOI: ri14.v12i2.682 
Roads to Recursion. Some historiographical remarks on a core category of Media Art | 76

ticipants and not a negative one, as described by Norbert Wiener for control purposes as seen from the perspective of first-level cybernetics from the 1940ies.

Between the two extremes there are some hybrids such as 'site-casting' - actually a CC, usually scheduled on smaller distances within a local community - or 'narrowcasting' / 'cablecasting', which denotes another not particularly extensive distribution network, but with some properties of 'broadcasting' in the sense of the 'mass media' concept.

The confusion between the definitions of the 'closed' and 'open' circuits is not only due to the later curricular and political, cultural and ideological petrifications. Its source can also betraced back to the early definition of "closed-circuit television" from the 1950s: In the glossary of a well-known book which describes the history of the electronic camera of this period, the following definition is given:

“CLOSED CIRCUIT. A television program not broadcast but confined to the studio. May be recorded if need be." ${ }^{\prime 18}$

The critical moment in the field of Closed Circuit video installations, where theoretical discourse and artistic practice in and about the medium diverge, was analyzed by Stuart Marshall at the same time by claiming that the artist's theories of video had "frequently developed into an examination of the notions of consciousness and selfhood", so letting the work suffer "from being at the same time the discourse of the medium and discourse about the medium [...] The confusion of logical typing or meta-levels that this work displays gives rise to a neuroticism in the works as theory, in that the theory serves to disavow [...] aspects of the art works." ${ }^{19}$

\section{Closed Circuit's Recursions in the Roaring Nineties: Development}

At the beginning of the 1990s, the concrete achievements and the developmental potential of Closed Circuit video installation were interpreted afresh with the aim of finding the common denominator it may have shared with the 'new media art'. As Horst Bredekamp claimed at that time, 
“If so-called interactive art and closed-circuit installation can be said to have a common denominator, then it is that they constantly question the other bodily senses in an ecstasy of the virtual and in televisual pixel storms. With varying aims in mind, a profusion of 'interactive' artworks have dedicated themselves to the disjuncture between visual representation and the loss of the body." 20

In the initial search for an interactive media art, Closed Circuit video installation thus proved a stumbling block on the way to a strict division of new computer-aided artworks from their respective precedents. The hidden presence and structural meaning of live video cameras in computer-led installations - in other words, the survival of Closed Circuit video installation within 'interactive media art' - had to be conceded, despite questionable classifications distingishing artificially between "interactive environments" and "interactive installations". ${ }^{21}$ In this context, a demarcation between earlier Closed Circuit video installation and its digital counterparts from the 1990s could only be finally ensured by means of an inadmissible reduction of the former to its "self-reflective" variants: "The cybernetic circle, in which the user involuntarily finds himself, permits reflection on his own role, going beyond the mere self-mirroring of closed-circuit installations of the seventies." 22 Despite this, computer-aided Closed Circuit video installations by Myron Krueger, David Rokeby and Lynn Herschmann are repeatedly invoked as key examples of "interactive media art". However, the role and significance of Closed Circuit video installation in/for "interactive media art" is also occasionally highlighted:

\begin{abstract}
"A further factor is decisive [...] in the development of interactive art: the principle of the visual closed-circuit installation, which was also introduced to the exhibition context [...] at the end of the sixties. [...] The technical constellation of closed-circuit structural organisation, in which the camera is trained on to the visitor, fulfills one of the most important aims in the striving for participation."23
\end{abstract}

In discussions about the genealogy and historiography of today's 'new' or 'interactive' media art, the majority clearly emphasizes the crucial role of Closed Circuit video installation. The founding director of ZKM in Karlsruhe, Heinrich Klotz stated:

ICONO14 | Año 2014 Volumen 12 N² 2 | ISSN: 1697-8293 | DOI: ri14.v12i2.682 


\begin{abstract}
"Attached to the history of video art is the parallel history of technical invention, such as, for instance, closed circuit installation, with which it became possible to incorporate the approaching viewer into the video image - at first with a slight delay, but before long in real time as well - such that the world of the art work could apparently be identified with the real space of the viewer." 24
\end{abstract}

In the course of the 1980s, a merging of the electronic 'eye' and 'brain' took place, as video and the digital computer increasingly began to demonstrate combined possibilities until then barely researched. The significance of Closed Circuit video technology for the construction of later VR (virtual reality) immersion rooms meanwhile had not been forgotten, as Margaret Morse has also pointed out:

"It is television that first raises the problem of constructing full-fledged parallel visible worlds and the linking them with our own [...] More completely interactive and immersive technologies are not different in kind - they are simply better informed about where you physically are in material space and, we might add, social space [...] Ongoing surveillance by machines is then a corollary of the feedback of data from interaction with machines $\left[\ldots . .{ }^{\prime 25}\right.$

In this one can see an anticipation of later strategies aimed at examining those aspects of (re)-presentation which relate to cognition theory, such as those which are a feature of new developments in media art and result from the disintegration of artistic and media "genre boundaries". ${ }^{26}$

Kathy Rae Huffman was even firmer in her according to Closed Circuit video technology the pioneering role in the history of today's interactive multi-media art:

"In the earliest actual practice, video was used in the same way as surveillance devices are today, it was employed to keep watch over and to observe reality [...] This act - creating electronic territory and involving the viewer in it as a physical entity - is a direct predecessor to contemporary, interactive multimedia art, and immersive technology."27

DOI: ri14.v12i2.682 | ISSN: 1697-8293 | Año 2014 Volumen 12 № 2 | ICONO14 
Even such a great champion of digital media art as Itsuo Sakane, writing in the catalogue of the first, self-organised exhibition on "interactive media art", has deemed early Closed Circuit video installation to be the first generation of "interactive" media art:

"It has become possible to instantaneously feedback the response from the viewers to the works thanks to video cameras, sound and optical sensors (detecting devices), interfaces giving access to information, and mostly to computers which enable high-speed data processing. The use of information engineering terms, such as "feedback" and "cybernetics", in the first generation interactive art emphases the inclination of the artists in those days towards new technology."28

In her plea for an art of intense bodily experience, M. L. Angerer, too, cites early Closed Circuit video installation:

"A review of the recent history of media art demonstrates, that especially in the field of video art [...] - even at the end of the 70s - a focus was placed on the body in space, the body as space, the body and its ego lost in space $^{29}[\ldots]$ I would suggest speaking about a new intensity in the experience of the body and beginning with the numerous examples in video and installation art, so that one can see the continuities and the new elements within this experience in the field of New Media Art." ${ }^{\prime 30}$

In the example relating to screen development given in a genealogy of the "new media" by Lev Manovich, it is particularly apparent that there had been no radical break with the past: "In my genealogy, the computer screen represents an interactive type, a subtype of the real-time type, which is [a] subtype of the dynamic type, which is a subtype of the classical type." ${ }^{\prime 1}$

The "real-time screen" should be seen in this context as the output-side of the Closed Circuit video system, whereby screen technology is explicitly introduced as a pre-requisite for VR, "telepresence" and "interactivity". ${ }^{32}$ Above all, it is its manipulation of real time that makes this technology so remarkable for Manovich:

ICONO14 | Año 2014 Volumen 12 Nº 2 | ISSN: 1697-8293 | DOI: ri14.v12i2.682 
"What is new about such a screen is that its image can change in real time, reflecting changes in the referent, whether the position of an object in space (radar), any alternation in visible reality (live video) or changing data in the computer's memory (computer screen). The image can be continually updated in real time. This is the third type of screen after classic and dynamic - the screen of real time." ${ }^{\prime 33}$

If it is rounded out with its input component - the live video camera - this attempt of genealogy indeed describes the achievement of visual interface technology as an indispensable element of many of today's computer-aided media installations. The definitions and remarks quoted here with regard to the role and significance of Closed Circuit video installation should not be taken as an attempt at an historical reduction of media art to the field of "video art", but to mark historiographical lineages for today's digital media installations from the Closed Circuit video installations.

Given the current phenomenon of 'Old Media Art Exhibitions' ${ }^{\prime 34}$ and the now institutionalized distinction between 'old' and 'new' media arts, this interesting and undoubtedly gratifying curatorial trend needs to be supplemented by the historiographical and theoretical infrastructure.

\section{Closed Circuit beyond the Digital Dogma: Conclusions}

\subsection{Closed Circuit video installations / Media Art in general: Fields of Inquiry}

1. Subject-Object Relationship.

Medium: Mirror; Metaphor: Narcissus; Material: Machine Vision

2. Constructions of Reality.

Reality and Virtuality: Fragment and Superposition

DOI: ri14.v12i2.682 | ISSN: 1697-8293 | Año 2014 Volumen 12 №2 | ICONO14 
Reality and Virtuality: Model and Construction

Reality and Virtuality: Narration and Interaction

3. System Models and Behavioral Patterns.

Silicon Meets Carbon: Animal, Human, Robot and Beyond

4. Game Concepts and Learning Processes.

Games-Rules-Learning: Ludic Aspects of Media Art

5. Data Collection and Monitoring.

On Watching of Watching: Media Art between the private and common space.

6. Telecommunication.

From Slow Scan-TV, Closed Circuit-TV, and Satellite to Telerobotics via Internet, WiFi, Mobile Phone, etc.

The displayed content-related categorization of Closed Circuit video installations (table) may represent general 'fields of inquiry' of both analogue and digital media art. The thousands of examples behind it show not least that as early as in the 1960s, media artists were becoming particularly interested in behavioral and systems theories, including the study of physical, biological and anthropological systems. If we project the barely 'specific' research field related to system models and behavioral patterns in media art onto the disciplinary plane, we can observe two decisive processes in the recent history of science: molecular biology is following its task of analyzing life at the molecular level while manipulating the results in order to overtake the evolution of 'life' from random and recursive processes ('nature'). At the same time, research into artificial life and robotics seeks to let machines appear 'alive' by transferring the principles of random or 'natural' life or its features to the artificial systems. ${ }^{35}$ While we are finding ourselves operating between the mechanization of 'living' and the 'revival'/'re-animation' of technology, 'systems-thinking' has become a commonplace. Already in what he terms "Cybernetic Explanation" (1967), the biologist, anthropologist and philosopher Gregory Bateson introduced feedback and redundancy as factors of the cybernetic explanation type. In one breath he named organisms in environments, ecosys-

ICONO14 | Año 2014 Volumen 12 N² 2 | ISSN: 1697-8293 | DOI: ri14.v12i2.682 
tems, thermostats, companies, and computers. Together with Bateson's ecological aesthetics and aesthetics of recursion, the questions of etiology and historiography have come closer to those of ethology and behavioural research, bearing clear implications for culture and the concept of culture (considering that visual cultural studies are still formulating their programs tin sharp distinction to the undisputable achievements of art history). With the re-definition of the concept of information ${ }^{36}$, as bio-semiotics and cyber-semiotics research has proposed, the deeper meaning of the avant-garde, asymptotic convergence of 'art' and 'life' could also be seen in the context of art history and media technology: Closed Circuit as an 'open system' addresses in this context its right to an evolution towards increasing complexity without the reciprocal playing-off of self-referential 'life' against 'hetero-referential' technique.

In order to arrive at an impartial view of media art that derives its pertinence from the spheres of both media theory and art history, it is therefore essential to overcome the emphatic opposition between what is 'specific to media' and what 'has become historical'. A historiography of 'new' media will have to counter 'post-historical' apocalyptic paranoia and fantasies of abolition (a 'post-biological' rhetoric within the realm of digital dogma ${ }^{37}$ ) with a hypothesis of continuity which does not construct pre-established harmonies in reverse gear (as if anything in art and visual culture as well as their theory had begun only in the 1990s), but develops tools for the registration and reproduction of both the 'new' and the 'old' media, materials, models, motives, and metaphors. Closed Circuit video installations based on these principles still offer a suitable experimental field for corresponding theses and historical as well as historiographical conclusions.

\section{Notes}

[1] See: Lev Manovich, "Database as a Genre of New Media" (conference paper), in "Chips and Bits"-Symposium, UCLA School of Film and Television, May 1997 and the conference paper at "Computing Culture: Defining New Media Genres", Center for Computing in the Arts, University of California in San Diego, May 1998. - Compare also: Victoria Vesna (ed.), Database Aesthetics: Art in the Age of Information Overflow (Minneapolis, MN: University of Minnesota Press 2007).

[2] See Slavko Kacunko, "Das (Medien-)Kunstwerk im Fokus der Genie-,Werk-, Rezeptionsund Interaktionsästhetik", in Werke im Wandel. Zeitgenössische Kunstzwischen Werk und Wirkung, ed. Lars Blunck (Munich: Silke Schreiber 2005), 125-152.

DOI: ri14.v12i2.682 | ISSN: 1697-8293 | Año 2014 Volumen 12 №2 | ICONO14 
[3] See especially: Slavko Kacunko, Closed Circuit Videoinstallationen. Ein Leitfaden zur Geschichte und Theorie der Medienkunst mit Bausteinen eines Künstlerlexikons" (Berlin: Logos 2004, in German). An extensive book includes descriptions of ca. 1.100 Closed Circuit video installations of the past fifty years (1.184 pages), documented also by ca. 13.000 images on DVD-ROM.

[4] 'Closed-circuit' describes a live transmission of audio visual signals resembling the method facilitated by radio and television: the direct 'closed-circuit' connection between apparatus for recording and broadcasting (loudspeaker or monitor/projector) arises by means of auditory or visual feedback, which is, in turn, the basis for an amplification of the signal. For the recipient, the direct presence of his own live video image and the relevant 'medium of reflection' is the most remarkable and at the same time the most disconcerting feature of the basic technology.

[5] “Closed-circuit or feedback - term for an installation, in which the result of its production is simultaneously its point of departure, for instance, a camera, whose video image is filmed by a monitor." Hans-Peter Schwarz, "Glossary" in: Medien-Kunst-Geschichte. Medienmuseum ZKM, Karlsruhe, ed. Hans-Peter Schwarz (Munich/New York: Prestel 1997), 187.

[6] “Closed-Circuit - feedback, "geschlossener Kreislauf". Usually understood today as the feeding back of visual signals, particularly in video installations; term employed for the process of recording a monitor image with a camera, which has just produced that monitor image." (Thomas Donga, "Glossary" in Der elektronische Raum. 15 Positionen zur Medienkunst. Kunst- und Ausstellungshalle der Bundesrepublik Deutschland, Bonn (0stfildern: Cantz 1998), 227.

[7] “The self-feeding, self-imaging, and environmental surveillance capabilities of closed-circuit television provide for some artists a means of engaging the phenomenon of communication and perception in a truly empirical fashion similar to scientific experimentation. This approach to the medium may in fact constitute the only pure television art, since the teleportation of encoded electronic-signal information is central to its aesthetics [...]." Gene Youngblood, Expanded Cinema (New York: Dutton 1970), 337/339.

[8] "Video [...] is able to convey in real-time an instantaneous simultaneity of events, which can merge man's inner and outer perceptions in a total Gestalt experience." Jud Yalkut, an unpublished manuscript (archive of the artist, Dayton, OH 1974), 3.

[9] "But in contrast, the closed-circuit, environmental videographers are trying to make use of what in the medium is not like film or other art. [...] In the last analysis, environmental (tapeless) video, the kind whose only product is the heightening of consciousness and the enlargement of useful experience, seems to me the only interesting video art." Allan Kaprow, "Video Art: Old wine, New Bottle", in Art Forum (New York 1974), 95.

[10] Wulf Herzogenrath, Mehr als Malerei. Vom Bauhaus zur Video-Skulptur (Regensburg; Lindinger + Schmid 1994), 11.

[11] “The camera and monitor, as [...] employed in closed circuit installation and performance, are considered to be the first (and thus emphatically the original) video-specific tools, [...] only in second place comes their narrative relationship to film or television." (Rudolf Frieling, "Kontext Video Kunst", in Dieter Daniels and Rudolf Frieling, Medien Kunst Interaktion. Die 80er und 90er Jahre in Deutschland (Vienna / New York: Springer 1999), 12.

ICONO14 | Año 2014 Volumen 12 N² | ISSN: 1697-8293 | DOI: ri14.v12i2.682 
[12] M. Rush also laid stress, in reference to early video practice, on the difference between the 'immediacy' of Closed Circuit video installation and the application of pre-produced videotape: “[...] For [...] early practitioners of video art [...] [it] was video's capacity for instantaneous transmission of image that [...] was most appealing, in addition to its relative affordability [...] the spontaneity and instantaneity of video were crucial. Video recorded and revealed instant time, whereas film had to be treated and processed." Michael Rush, New Media in Late 20th-Century Art (London: Thames \& Hudson 1999), 83-84.

[13] "Only here in the face of the cult of the instant experience, which one wants to relate to us, does this process as such become clearer. This cult can only be justified, when we speak of video experience, which has been processed physically or mentally in closed circuit, and has been conveyed via that medium, the transmission of which has been reacted to by a participating individual. Thus a video performance or installation is appropriate to the medium only when it makes sensible use of the effects of perception." Wolf Kahlen, "FERNSEHEN oder Das Kissen unter den Ellbogen im Fenster und VIDEO oder Wie man Brillen putzt", in Vídeo, El temps i l'espai, Sèries Informatives 2 (Barcelona: Collegi d'arquitectes de Catalunya, Institut Alemany de Barcelona 1980), 11.

[14] David Ross, "Video: the Success of its Failure", in 3e biennale de Lyon (exhibition catalogue Paris 1995), 433.

[15] Ibid, 437.

[16] Juan Downey, "Feedback (About the Basic Text)", in Vídeo, El temps i l'espai, Sèries Informatives 2 (Barcelona: Collegi d'arquitectes de Catalunya, Institut Alemany de Barcelona 1980), 5.

[17] Eugeni Bonet, “Closed-Circuit Installations, Video Objects or Video Sculptures, Video Environments, Multi-Channel Installations, Video Performances...", in Vídeo, El temps i l'espai, Sèries Informatives 2 (Barcelona: Collegi d'arquitectes de Catalunya, Institut Alemany de Barcelona 1980), 29.

[18] Albert Abramson, Electronic Motion Pictures: A History of the Television Camera. (New York: Arno Press 1974 [1st. ed. 1955]), 200.

[19] Stuart Marshall, "Video Art, The Imaginary and the Parole Vide", in Studio International. Journal of Modern art (may/june, New York 1976), 243. The text has appeared under the same title also in: New Artists Video. A Critical Anthology, ed. Gregory Battcock (New York: A Dutton Paperback 1978).

[20] Horst Bredekamp, "Tastende Closed Circuits", in: CeBIT 1995 exhibition catalogue (Berlin: Triad 1995), 7-8.

[21] Söke Dinkla, Pioniere Interaktiver Kunst von 1970 bis heute (Ostfildern: Cantz 1997), 10. (translation from German: Helen Shiner).

[22] Söke Dinkla, “Das flottierende Werk. Zum Entstehen einer neuen künstlerischen Organisationsform", in Peter Gendolla et al., Formen interaktiver Medienkunst (Frankfurt am Main: Suhrkamp 2001), 87.

[23] Dinkla, Pioniere, 38-40. - Annette Hünnekens also wrote about the "principle of closed circuit installation", which she discussed in the same breath as "database" work on videodisc. See

DOI: ri14.v12i2.682 | ISSN: 1697-8293 | Año 2014 Volumen 12 N² | ICONO14 
Annette Hünnekens, Der bewegte Betrachter, Theorien der interaktiven Medienkunst (Cologne: Wienand 1997), 22. - See also note 1. above.

[24] Heinrich Klotz, Kunst der Gegenwart. Museum für Neue Kunst: ZKM, Karlsruhe (Munich / New York: Prestel 1997), 22.

[25] Margaret Morse, Virtualities. Television, Media Art, and Cyberculture (Bloomington / Indianapolis: Indiana University Press 1998), 6-7.

[26] John G. Hanhardt, "Theater der Erinnerung: Film und Video in einem Zeitalter der Neuen Medien“, in: Artintact 4. CD-rom Magazin interaktiver Kunst ZKM, Karlsruhe (Ostfildern: Cantz 1997), 15.

[27] Kathy Rae Huffman, "Video, networks, and Architecture. Some Physical Realities of Electronic Space", in Electronic Culture. Technology and Visual Representation, ed. Timothy Druckrey (New York: Aperture 1996), 203-204.

[28] Itsuo Sakane, "Introduction" in: Wonderland of Science Art - Invitation to Interactive Art (Kanagawa: Kanagawa International Art \& Science Exhibition 1989), 4.

[29] Marie-Luise Angerer, “I am suffering from a spatial hangover. Körper-Erfahrungen im NeuenMedienKunst-Kontext, in Peter Gendolla et al., Formen interaktiver Medienkunst (Frankfurt am Main: Suhrkamp 2001), 177.

[30] Ibid, 182.

[31] Lev Manovich, The Language of New Media (Cambridge, Mass. / London: The MIT Press 2001), 103.

[32] Ibid, 94.

[33] Ibid, 99.

[34] See for example exhibition "Mind Frames - Media Study at Buffalo 1973-1990" (ZKM Karlsruhe 2007) and "Art and the Moving Image, 1963-1986" (Museo Nacional Centro de Reina Sofia 2006).

[35] The range of the system-theoretical contextualizations of 'life' represents on the other side the theoretical implications related to the contemporary 'bio-art' and 'bio-media'. It could be exemplified on one side by Humberto R. Maturana and his almost vitalist thesis about the irreducibility of life. That again can be seen as the flip side of the cybernetic theory (of 'first order', as in opposition to the later bio-semiotic approaches) of Norbert Wiener with its reducibility of everything to the input / output model. To the mediators between the two belongs certainly the biologist Ludwig von Bertallanffy with his theory of learning-ability of feedback systems.

[36] See Søren Brier. Cybersemiotics. Why Information is not enough (Toronto / Buffalo / London: University of Toronto Press 2008) and Jesper Hoffmeyer, "God, Matter, and Information", in Information and the Nature of Reality: From Physics to Metaphysics, ed. Niels Henrik Gregersen and Paul Davis (Cambridge: University of Cambrige Press), 185-204. - Extensive bibliography may be found online on http://biosemiotics.org/.

[37] For discussion about the continuity between the analogue and digital 'code' see Jens Schröter and Alexander Böhnke (eds.), Analog, Digital : Opposition oder Kontinuum?: zur Theorie und Geschichte einer Unterscheidung (Bielefeld: Transcript 2004).

ICONO14 | Año 2014 Volumen 12 Nº 2 | ISSN: 1697-8293 | DOI: ri14.v12i2.682 